\title{
Mathematical Model of Housing Loans
}

\author{
Xiangrong Li \\ College of Mathematics and Information Science, Guangxi University, Nanning, China \\ E-mail:xrli68@163.com \\ Received July 27, 2010; revised August 30, 2010; accepted September 5, 2010
}

\begin{abstract}
Currently, that individual use housing mortgage loans to buy houses has become a hot topic, and residents are very concerned about the debt repayment ways of individual housing mortgage loans. In this paper, using the time value of money principle, we establish equal principal and interest repayment model. Furthermore we test its validation and illustrate its specific application with an example in the economic life.
\end{abstract}

Keywords: Mathematical Model; Housing Mortgage Loans; Equal Principal and Interest Repayment

\section{Introduction}

With the development of economic and society, using housing mortgage loans, personal buying house becomes a more and more common phenomenon [1]. The so-called mortgage is that consumers purchase what they need by borrowing money from banks, at the same time, they must mortgage what they buy to banks as collateral, and within the agreed time, consumers should repay the loan and pay interest in accordance with the agreed time intervals. However, most people do not know much about the repayment of some of the issues. We try to reveal its contents from the mathematical model [2].

\section{Modeling}

\subsection{Basic Assumptions}

1) Repayment period is fixed;

2) Interest rates do not fluctuate;

3) Interest rate and term are calculated on a monthly basis;

4) Each repayment is occurred at the last day of current [3].

\subsection{Equal Principal and Interest Repayment Modeling}

Set $\mathrm{P}$ is the loan principal, $i$ is monthly interest rate, $n$ is the number of months for the repayment, and $\mathrm{A}$ is the monthly repayment amount.

Using the time value of money principle, the above economic problems can be converted into ordinary annu- ity present value formula, that is

$$
P=A(1+i)^{-1}+A(1+i)^{-2}+A(1+i)^{-3}+\cdots+A(1+i)^{-n}
$$

multiply with the same $(1+i)$ both sides of the equation, then

$$
\begin{aligned}
P(1+i) & =A+A(1+i)^{-1}+A(1+i)^{-2} \\
& +A(1+i)^{-3}+\cdots+A(1+i)^{-(n-1)}
\end{aligned}
$$

2-type phase for reduction, then

$$
P=A \cdot \frac{1-(1+i)^{-n}}{i}=A(P / A, i, n)
$$

Where, $\frac{1-(1+i)^{-n}}{i}$ is present value annuity factor, denoted by $(P / A, i, n)$, direct access to 'the present value of annuity factor table'.

\subsection{Calculating the Monthly Repayment Amount}

$$
A=\frac{P}{(P / A, i, n)}
$$

\subsection{Calculation of the Total Interest}

$$
I=P-n A
$$

\section{Validation and Application of the Model}

Table 1 is equal principal and interest repayment method 
Table 1. Survey provided by Shanghai Housing Accumulation Fund Management Center (take 100,000 yuan as example).

\begin{tabular}{|c|c|c|c|c|c|c|}
\hline period (years) & $\begin{array}{l}\text { the number of } \\
\text { months }\end{array}$ & $\begin{array}{l}\text { monthly rate } \\
(\% 0)\end{array}$ & year rate (\%) & $\begin{array}{l}\text { equal monthly } \\
\text { payments (yuan) }\end{array}$ & $\begin{array}{l}\text { total principal and } \\
\text { interest (yuan) }\end{array}$ & total interest (yuan) \\
\hline 1 & 12 & 3.15 & 3.78 & 8504.90 & 102058.80 & 2058.80 \\
\hline 2 & 24 & 3.15 & 3.78 & 4332.71 & 103984.97 & 3984.97 \\
\hline 3 & 36 & 3.15 & 3.78 & 2942.62 & 105934.39 & 5934.39 \\
\hline 4 & 48 & 3.15 & 3.78 & 2248.07 & 107907.56 & 7907.56 \\
\hline 5 & 60 & 3.15 & 3.78 & 1831.74 & 109904.45 & 9904.45 \\
\hline 6 & 72 & 3.525 & 4.23 & 1575.02 & 113401.42 & 13401.42 \\
\hline 7 & 84 & 3.525 & 4.23 & 1377.49 & 115709.42 & 15709.42 \\
\hline 8 & 96 & 3.525 & 4.23 & 1229.66 & 118046.95 & 18046.95 \\
\hline 9 & 108 & 3.525 & 4.23 & 1114.94 & 120413.90 & 20413.90 \\
\hline 10 & 120 & 3.525 & 4.23 & 1023.42 & 122810.20 & 22810.20 \\
\hline 11 & 132 & 3.525 & 4.23 & 948.76 & 125235.73 & 25235.73 \\
\hline 12 & 144 & 3.525 & 4.23 & 886.74 & 127690.40 & 27690.40 \\
\hline 13 & 156 & 3.525 & 4.23 & 834.45 & 130174.09 & 30174.09 \\
\hline 14 & 168 & 3.525 & 4.23 & 789.80 & 132686.66 & 32686.66 \\
\hline 15 & 180 & 3.525 & 4.23 & 751.27 & 135227.99 & 35227.99 \\
\hline
\end{tabular}

Table 2. Equal principal and interest repayment calculated by the above model.

\begin{tabular}{|c|c|c|c|c|c|c|}
\hline period (years) & $\begin{array}{c}\text { the number of } \\
\text { months }\end{array}$ & $\begin{array}{l}\text { monthly rate } \\
(\% 0)\end{array}$ & year rate $(\%)$ & $\begin{array}{l}\text { equal monthly } \\
\text { payments (yuan) }\end{array}$ & $\begin{array}{l}\text { total principal and } \\
\text { interest (yuan) }\end{array}$ & total interest (yuan) \\
\hline 1 & 12 & 3.15 & 3.78 & 8504.90 & 102058.80 & 2058.80 \\
\hline 2 & 24 & 3.15 & 3.78 & 4332.70 & 103984.80 & 3984.80 \\
\hline 3 & 36 & 3.15 & 3.78 & 2942.60 & 105933.60 & 5933.60 \\
\hline 4 & 48 & 3.15 & 3.78 & 2248.10 & 107908.80 & 7908.80 \\
\hline 5 & 60 & 3.15 & 3.78 & 1831.70 & 109902.00 & 9902.00 \\
\hline 6 & 72 & 3.525 & 4.23 & 1575.00 & 113400.00 & 13400.00 \\
\hline 7 & 84 & 3.525 & 4.23 & 1377.50 & 115710.00 & 15710.00 \\
\hline 8 & 96 & 3.525 & 4.23 & 1229.70 & 118051.20 & 18051.20 \\
\hline 9 & 108 & 3.525 & 4.23 & 1114.90 & 120409.20 & 20409.20 \\
\hline 10 & 120 & 3.525 & 4.23 & 1023.40 & 122808.00 & 22808.00 \\
\hline 11 & 132 & 3.525 & 4.23 & 948.800 & 125241.60 & 25241.60 \\
\hline 12 & 144 & 3.525 & 4.23 & 886.70 & 127684.80 & 27684.80 \\
\hline 13 & 156 & 3.525 & 4.23 & 834.40 & 130166.40 & 30166.40 \\
\hline 14 & 168 & 3.525 & 4.23 & 789.80 & 132686.40 & 32686.40 \\
\hline 15 & 180 & 3.525 & 4.23 & 751.30 & 135234.00 & 35234.00 \\
\hline
\end{tabular}


list of individual housing loan (provided by Shanghai Housing Accumulation Fund Management Center).

Now we will test the above model's validation with Table 1, then get Table 2:

The data of Table 2 and Table 1 are coincident. The above laboratory data show that the model is more realistic.

\section{Conclusions}

See from the above results, the model is basic good. It can meet generally the daily needs of people.

Most people know that there are many ways of mortgage repayment. In addition to equal principal and interest repayment, there are equal principal repayment, a debt service, equal increments and equal decrease, and so on. Among them, the most common repayments are equal principal and interest repayment and equal principal repayment [4].

In this paper, we only establish equal principal and in- terest repayment model. Other models (such as equal principal repayment model) are yet to be established. We will make further study of its.

\section{References}

[1] Y. P. Zhang and W. Q. Yuan, "Mathematical model of mortgage loans," Journal of Yellow River Conservancy Technical Institute, Vol. 18, No. 1, 2006, pp.

[2] S. C. Matthew, C. Garriga and D. Schlagenhauf, "The loan structure and housing tenure decisions in an equilibrium model of mortgage choice," Review of Economic Dynamics, Vol. 12, No. 3, 2009, pp.444-468.

[3] V. Hartarska and C. Gonzalez-Vega, "Evidence on the effect of credit counseling on mortgage loan default by low-income households,Journal of Housing Economics," Vol. 15, No. 1, 2006, pp. 63-79.

[4] A. Sumit and W. Brent, "Ambrose, Souphala Chomsisengphet, Chunlin Liu, An empirical analysis of home equity loan and line performance,” Journal of Financial Intermediation, Vol. 15, No. 4, 2006, pp. 444-469. 